DOI https://doi.org/10.18551/rjoas.2020-09.14

\title{
MARKET STRUCTURE AND MACROECONOMIC ON INDUSTRY PERFORMANCE OF RURAL BANKS IN SOUTHEAST SULAWESI PROVINCE OF INDONESIA
}

\author{
Sarita Buyung*, Syaifuddin Dedy Takdir, Hajar Ibnu, Madjid Rahmat \\ Faculty of Economy and Business, Halu Oleo University, Kendari, Indonesia \\ *E-mail: buyungsarita buyung@yahoo.com
}

\begin{abstract}
This study aimed to examine the effect of macro-economy and market structure of the industry's performance of rural banks (BPR) in Southeast Sulawesi province using data quarter of the year 2011 to 2013, total population of 12 rural banks in Southeast Sulawesi. The data were analyzed using panel data by combining a cross-sectional data and time series. The theory used in this study is the Structure-Conduct-Performance (SCP) that proxy to Market concentration (MC) and Relative Efficiency (RE) which proxy to Market Share Deposits (MSD). The study found that (Market Concentration) lowered the performance of (BPR bank industry) and increasing Market Share Deposits improved the performance of BPR bank industry. Furthermore, large (MSD) and greater capital adequacy ratio (CAR), as well as Log to total assets (LTA) and the size of banks improved the performance of BPR bank industry. On the contrary, the market concentration, increasing liabilities to total assets (LTTA), growing non-Performing Loan (NPL) lowered the performance of BPR bank industry in Southeast Sulawesi. Furthermore, the level of LDR and (PIFL) was not able to improve the performance of BPR industry in Southeast Sulawesi Province. This indicates that many (BPR) banks operating during the study period were not efficient in the provision of loans in other words the majority of BPR banks operating in Southeast Sulawesi province were still in a loss position.
\end{abstract}

\section{KEY WORDS}

Structure conduct performance, relative efficiency theory, macroeconomic performance industrial rural bank, panel data analysis.

This study aimed to assess the Market Structure and Macro economy on the performance of rural bank (BPR) Industry in Enhancing Economic Security of Southeast Sulawesi Province. One of the monetary program is to enhance the role of rural banks (BPR) in the provision of services to Small Medium Enterprises (SMEs) by strengthening BPR institution and fixing various financing structures, human resources, consumer tastes, supporting infrastructure, and operational efficient BPR (Bank Indonesia,2006).

The role of banks in the economy is very vital especially in money market. BPR present to provide financial products similar to other conventional bank proved to have better penetration compared to other banks, especially for Micro and Small Enterprises (MSEs).King and Levine (1993) stated that the bank is a financial institution relating to the supply and demand of money in society, individuals, companies and governments either directly or indirectly, will boost economic growth.

BPR's unique characteristics easier in lending and higher savings benefits compared to conventional become the main attraction that BPR is still in demand. BPR has its market segmentation to market their products to the middle level community, which may be the reason for BPR to be able to survive until today.

In Southeast Sulawesi, the development of commercial banks has also been followed by the development of BPR based on asset and credit growth during the reporting period; from 12 BPRs which consists of four private BPRs and eight BPR sowned by local government. In quarter IV (2013), BPR assets reached 122.46 billion, growing by $18 \%$, experienced a considerable significant slowdown compared with an increase of assets in the same period in 2012 amounted to $29.14 \%$. Slowing growth in assets was also driven by 
slower growth in lending by $17.85 \%$, lower than the growth in the same position in 2012 amounted to $39.05 \%$ (Report of Bank Indonesia, 2013).

Furthermore, inefficient operations will lead to their inability to compete in obtaining public funds and passing it back to the community. Therefore, an increase in the efficiency of the banking institutions, especially in good cash management will be able to increase the maximum profit.

\section{LITERATURE REVIEW}

The study of the relationship between banking efficient and the bank's performance has been widely studied in developed countries America and Europe by using StructureConduct-Performance (SCP) and Relative Efficiency (RE) paradigm. According to Heather (2002) SCP paradigm approach is started by overlook at the structure of the industry and how the industry is organized into various different markets.

Some of the Internal and external factors that affect the performance of the BPR industry assessed by way of the paradigm Structure-Conduct-Performance (SCP) and Relative Efficiency (RE). According to Heather (2002) SCP paradigm approach can be started by looking at the structure of the industry and how the industry is organized into various different markets. Furthermore, we give the view that the behavior of the company in relation to the price is determined by the output of the industrial structure. Therefore, to see how that is taken by the company in the action, then we can analyze their performance.

There are still limited numbers of research conducted on the relationship between market structure and achievements of rural banks (BPR) in developing countries. Therefore, this study will look at the structure of the market, market share and growth of inflation on the performance of rural banks (BPR) in Southeast Sulawesi province of Indonesia. The phenomenon of bank performance BPR will be a concern because BPR is a type of banking business institutions that have important role in serving and fulfill the needs of the community in the field of financial services, especially for Small and Micro Enterprises (SMEs).

Market share is a proxy of the industry's sales of goods or services that are controlled by the company. Analysis of market share reflects marketing performance associated with the company's competitive position within the industry. There are two major theories about market share is SCP (structure conduct performance) and the theory of efficiency. SCP theory is a model for linking the structure of the market with the company's behavior and performance. While the efficiency theory is a model that describes how operational efficiency increase of a company is able to affect the performance of the company.

Another school alternative theory is the Relative Efficiency (RE). This theory contradicts with the assumption of SCP stream, where it is believed that the efficiency of the company may result in high performance margins, which in turn could increase its market share. RE stream worrying that if the regulation setting is too tight against the structure of the market (as recommended flow SCP) it would reduce the incentive companies to increase efficiency (Arianto, 2004).

Many empirical studies have been conducted to test relationship with the market structure of the banking performance in the industry generally uses the paradigm StructureConduct-Performance (SCP), such research have been carried out by Heggestad and Minggo (1977), Rhoades (1982) and Spellman (1981) and has been criticized by Gilbert (1984b), Osborne and Wendel (1983) because it found a lot of inequality, difference, and strong dissatisfaction of this approach.

Therefore, the Theory Relative Efficiency (RE) to provide an alternative explanation to the theory of SCP. Theory of Relative Efficiency (RE) states that the relationship between market structures with the performance of individual banks depends on the efficiency of the bank itself in its operations. If a bank with a high degree of efficiency compared with rivals, because of their low cost structures, the bank can apply one of these strategies; (i) the bank can maximize profits by maintaining price; (ii) the most efficient banks will gain increased market share and this will make the efficiency of the power booster (driving force) on the back of market concentration (Kuncoro, 2003). 


\section{METHODS OF RESEARCH}

This research use Pooled analysis of data to analyze the effect of market structure variables and macroeconomics of the industry's performance rural banks (BPR) in Improving the Economic Security of Southeast Sulawesi Province. This method use with Ordinary Least Squares (OLS) by combining the data time series and cross-section Khrawish, HA (2011) with the help of Eviews 6.1. The model was developed based on these equations with the research objectives following regression equation:

$$
\pi_{i t}=\alpha_{0}+\beta_{1} M C+\beta_{2} M S+\sum_{\alpha i} x_{i}
$$

Where: the measurement of the performance of the bank, MC is Market concentration as a proxy measure of market structure, MSD is a deposit market share as a proxy measure of the relative efficiency variable, and is a vector of control variables as special measurement bank (bank-specific variables) as proposed by Sastrosuwito, S and Suzuki, Y (2012).

Based on the formula equation (1), then for testing hypotheses in Indonesian banking industry will be based on the equation as:

$$
\begin{aligned}
& \pi_{i t}=\alpha_{0}+\beta_{1} M C_{i t}+\beta_{2} M S_{i t}+\beta_{3} P I F L_{i t}+\beta_{4} L D R_{i t}+\beta_{5} L T T A_{i t}+\beta_{6} N P L_{i t}+\beta_{7} C A R_{i t} \\
& +\beta_{8} L T A_{i t}+\varepsilon_{i t}
\end{aligned}
$$

Where: the bank's performance is the dependent variable in this study $\left(\pi_{i t}\right)$ as measured by return on assets (ROA). While the independent variables will be measured by the Market concentration (MC) is a proxy of market structure variables to prove the theory Structure Conduct Performance (SCP) and Market Share Deposit (MSD) is a proxy variable for the efficiency of the relative who used to prove the theory of Relative Efficiency (RE). Further measurements Macroeconomic variables are used Inflation Growth (PIFL) and special variable bank (bank-specific variables) are variables bank risk is the loan to deposit ratio (LDR), liabilities to total assets (LTTA), Non-Performing Loans (NPLs), Capital adequacy ratio (CAR). Variable size is log total bank assets (LTA) is also often used to measure the economic scale bank.

Based on the research problem, the dependent variable in this study is the industry's performance rural banks (BPR) in Southeast Sulawesi Province which proxies as a measure return on Assets (ROA). Return on assets (ROA) is an assessment of the efficiency of the bank's management, because these measurements show the ability of banks to use all of its assets to obtain net income (Rose, 2002). Furthermore, ROA is the bank's ability to generate revenue by the number of its assets are measured by net income divided by total assets (\%) Goldberg and Rai (1996)

Market concentration (MC) is a proxy for the market structure which is used to prove the theory of SCP. Use of this paradigm with the assumption that the market in the form of oligopoly behavior that often called as collusion hypothesis means that the performance of the company will increase if there is collusion among companies in the industry such as the theory of oligopoly in those perfect competition (Church \& Ware, 2000). In general, the measurement of market concentration using the Herfindahl Index $(\mathrm{HHI})$ is done to calculate the market share of deposits of any bank in the market and summing the squared market share (Athanasoglou, Brissimis, \& Delis, 2005). If the value of the Herfindahl index below 1000 then it is said to be a concentration of the market. It is known that Herfindahl index value of 1000 to 1800 are simple market concentration, and the Herfindahl index value exceeds 1800 then said to occur high market concentration (Gilbert \& Zaretsky, 2003).

Market Share Deposit (MSD) is the ability of banks to dominate deposits industrial market, as measured by total deposits (demand deposits, savings deposits, and deposits) divided by the total bank deposits market in the banking industry (\%) Chirwa, (2001). Market share deposit is a proxy that is used to prove the theory of relative efficiency (RE). Paradigm 
(RE) states that the high market share due to the low production costs and increasing market share will increase profits (Hannan, 1991). The concept of market share as proposed by Smirlock (1985) that the market share in the banking context is better than the market concentration, because efficiency of some banks in carrying out their activities maximum increases above normal profits.

Inflation Growth (PIFL). Effect of inflation is also very important to determine the performance of banks. In general, the high rate of inflation is the same with a high interest rate loan and will ultimately increase revenue. However, Perry (1992) states that the effects of inflation on bank performance depends on whether inflation is anticipated or not. If inflation is anticipated fully and interest rate adjustments, then the result will be a positive influence on profits.(Rasiah, 2010) In this study uses the data quarterly inflation growth. Therefore, inflation is calculated based on the average growth per three-month inflation. Growth Inflation = TW0 inflation - inflation TW1 (Riva, 2009).

Loan to deposit ratio (LDR) is Represents the ability of banks to provide credit to customers with a guarantee of customer deposits as measured by total loans divided by total deposits coupled with Bank Indonesia liquidity credit, plus a core capital (\%) Molyneux \& Forbes (1995) LDR is an assessment of the extent to which the bank gave the credit to customers with a number of customer deposits in the bank, the higher this ratio, the lower the liquidity of banks that serve as the guarantor of funds to finance the larger credit (Sinkey, 1983).

Liabilities to total assets (LTTA) is the ability of banks to obtain loans with total assurance that its assets are measured of total bank debt divided by total assets their got (\%) (Golberg \& Rai, 1996). Liabilities to total assets ratio is a measure of the level of risk of the banking operations. The greater this ratio will affect the higher the risk of the bank, because larger amount of debt compared to the total assets owned by the bank. Thus, the bank will bear the cost of debt servicing a very large bank as proposed by Basir (2000) that the amount of liabilities to total assets of banks, it will bear the huge debt Risk. NonPerforming Loan (NPL) ratio is the total of non-performing loans to total loans. Credit Risk is the risk faced by the bank due to channeling funds in the form of loans to the public (Masyud Ali, 2006).

Non Performing Loan (NPL) reflects the level of credit risk faced by banks, the smaller the NPL, then the less the credit risk borne by the bank. Banks to provide credit should conduct an analysis of the debtor's ability to repay its obligations. Thus, if a bank has a high non-performing loan (NPL), it will increase both the cost of provisioning costs of productive assets and other costs, affecting the performance of the bank.

Capital adequacy ratio (CAR) is the ability of bank capital to cover potential losses on lending activities and trading securities are measured by the bank's capital divided by the weighted average risky assets (\%) (Bank International Settlement (BIS) and Bank Indonesia (2002), Bourke (1989) stated that the capital is a source of cheap funds because it does not have the burden of costs; therefore it will have a positive relationship to profits.

Log Total assets (LTA) is a measure of scale economies as a reflection of its bank bank size as measured by the logarithm total assets. (Chirwa, 2001). This concept explains that the level of the bank size allows for a reserve fund that can be used to invest massively and easy to carry out the investment portfolio (Smirlock, 1985). The increase in total assets will provide more opportunities for institutional investment banking and bank merging certainly in the long term will increase profits (Akhigbe \& McNulty, 2003).

\section{RESULTS AND DISCUSSION}

The present study uses an unbalanced panel data of Rural Banks (BPR) in Southeast Sulawesi during period of $2011-2013$ (the summary of descriptive statistics of the variable used has been presented in Table 1). The econometrics analysis of model (2) and (3) confronts the following issues. First, we test for stationary of the panel, using a unit root test for unbalanced panels. Second, we examine whether individual effects are fixed or random. 
Table 1 - Analysis Descriptive

\begin{tabular}{|c|c|c|c|c|c|c|c|c|c|}
\hline & ROA? & MC? & MSD? & PIPL? & LDR? & LTTA? & NPL? & CAR? & LTA? \\
\hline Mean & -11.02822 & 1178.266 & 23.18422 & 5.420000 & 117.6127 & 74.53333 & 4.630056 & 37.52256 & 22.55713 \\
\hline Median & -11.24000 & 212.4687 & 14.57500 & 5.250000 & 97.94000 & 79.80500 & 1.785000 & 25.28500 & 22.44650 \\
\hline Maximum & 18.20000 & 7784.533 & 88.23000 & 5.920000 & 556.0700 & 96.34000 & 39.67000 & 504.8000 & 23.93000 \\
\hline Minimum & -59.28000 & 0.160000 & 0.400000 & 5.090000 & 18.90000 & 6.950000 & 0.050000 & -8.880000 & 21.02900 \\
\hline Std. Dev. & 16.89871 & 2060.359 & 25.45500 & 0.361551 & 74.33592 & 20.27232 & 8.556518 & 57.47824 & 0.803763 \\
\hline Skewness & -0.491042 & 1.905955 & 1.245535 & 0.603536 & 3.699576 & -1.688992 & 2.918953 & 6.232952 & 0.105975 \\
\hline Kurtosis & 2.828686 & 5.284834 & 3.306016 & 1.500000 & 19.15195 & 5.501961 & 10.75433 & 49.94361 & 1.757527 \\
\hline Jarque-Bera & 3.726885 & 74.06671 & 52 & & 23 & 66.2 & 353 & 8846.631 & 5.957479 \\
\hline Probability & 0.155138 & 0.000000 & 0.000007 & 0.000958 & 0.000000 & 0.000000 & 0.000000 & 0.000000 & 0.050857 \\
\hline Sum & -992.5400 & 106043.9 & 2086.580 & 487.8000 & 10585.14 & 6708.000 & 416.7050 & 3377.030 & 2030.142 \\
\hline Sum Sq. Dev. & 25415.40 & $3.78 \mathrm{E}+08$ & 57668.19 & 11.63400 & 491798.8 & 36576.07 & 6516.046 & 294033.6 & 57.49714 \\
\hline Observations & 90 & 90 & 90 & 90 & 90 & 90 & 90 & 90 & 90 \\
\hline Cross sections & 10 & 10 & 10 & 10 & 10 & 10 & 10 & 10 & 10 \\
\hline
\end{tabular}

The second issue is the choice between the fixed effect (FE) and the random effect (RE) models. As indicated by the Hausman test on model (3) (see Table 4), the difference in coefficients between FE and RE is systematic, providing evidence in favour of the FE model. Furthermore, the estimation results show that individual effects are present, since the relevant F-statistic is significant at the $1 \%$ level.

Statistical analysis of the effect of the market structure and macro economy on the performance of BPR in Southeast Sulawesi province is presented in Table 2. The data analysis employed in this study is pooling data testing two models combining Fixed-effect and Random-effect.

Table 2 - FE and RE Estimation and specification test - Dep. Variable ROA

\begin{tabular}{|l|l|l|l|l|l|}
\hline \multirow{2}{*}{\begin{tabular}{l} 
Variable \\
\cline { 3 - 6 }
\end{tabular}} & Fixed Effects & Random Effects & Prob. & Coef. & Prob. \\
\hline C & -374.7360 & 0.0000 & -391.9247 & 0.0000 \\
\hline MC & $\beta_{1}$ & -0.006886 & $0.0001^{* * *}$ & -0.006283 & $0.0014^{* * *}$ \\
\hline MSD & $\beta_{2}$ & 0.407543 & $0.0186^{* *}$ & 0.381766 & $0.0310^{* *}$ \\
\hline PIFL & $\beta_{3}$ & 1.851519 & 0.2710 & 1.678992 & 0.5844 \\
\hline LDR & $\beta_{4}$ & 0.001549 & 0.8831 & 0.013310 & 0.3202 \\
\hline LTTA & $\beta_{5}$ & -0.157789 & $0.0556^{*}$ & -0.194870 & $0.0051^{* *}$ \\
\hline NPL & $\beta_{6}$ & -0.342325 & $0.0225^{* *}$ & 0.119378 & 0.4408 \\
\hline CAR & $\beta_{7}$ & 0.021471 & $0.0478^{* *}$ & 0.031298 & $0.0943^{*}$ \\
\hline LTA & $\beta_{8}$ & 16.16764 & $0.0000^{* * *}$ & 16.91616 & $0.0000^{* * *}$ \\
\hline R-squared & 0.656700 & & 0.528253 & \\
\hline Adjusted R-sq. & 0.622794 & & 0.481661 & \\
\hline F-statistic & 19.36814 & & 11.33777 & \\
\hline Prob. (F-stat.) & 0.000000 & & 0.000000 & \\
\hline
\end{tabular}

${ }^{* * *}=$ Significant.01; ${ }^{* *}=$ Significant $.05 ;{ }^{*}=$ Significant.

The result of Hausmant test on the two models indicates that the best is Fixed-effect where $\mathrm{R}^{2}=.66, \mathrm{~F}=19.37, \mathrm{p}=.01$ (Table 3 ). This means that $66 \%$ of the change of return on assets $(R O A)$ variable can be explained by all independent variables in this analysis.

The effect of each independent variable on the performance of the BPR industry can be seen in Table 4 showing that the Market concentration (MC) has a negative effect on the performance of BPR industry, this effect provides an indication that the banking market structure is still dominated by conventional banks, especially BRI and Bank Sultra as major competitors of bank BPR in some districts of Southeast Sulawesi province. Furthermore, the operating costs in capturing markets are high because BPR still promote them among banking industry business, so high concentration of the market has reduced the performance of BPR industry. 
Table 3 - Regression Analysis (Hausman Test)

\begin{tabular}{|c|c|c|c|c|}
\hline Variable & Coefficient & Std. Error & t-Statistic & Prob. \\
\hline $\mathrm{C}$ & -374.7360 & 29.37761 & -12.75584 & 0.0000 \\
\hline MC? & -0.006886 & 0.001689 & -4.078063 & 0.0001 \\
\hline MSD? & 0.407543 & 0.169689 & 2.401704 & 0.0186 \\
\hline PIPL? & 1.851519 & 1.670559 & 1.108323 & 0.2710 \\
\hline LDR? & 0.001549 & 0.010501 & 0.147510 & 0.8831 \\
\hline LTTA? & -0.157789 & 0.081260 & -1.941786 & 0.0556 \\
\hline NPL? & -0.342325 & 0.147173 & -2.326005 & 0.0225 \\
\hline CAR? & 0.021471 & 0.010685 & 2.009418 & 0.0478 \\
\hline LTA? & 16.16764 & 1.544600 & 10.46720 & 0.0000 \\
\hline Variable & Coefficient & Std. Error & t-Statistic & Prob. \\
\hline $\mathrm{C}$ & -374.7360 & 29.37761 & -12.75584 & 0.0000 \\
\hline MC? & -0.006886 & 0.001689 & -4.078063 & 0.0001 \\
\hline MSD? & 0.407543 & 0.169689 & 2.401704 & 0.0186 \\
\hline PIPL? & 1.851519 & 1.670559 & 1.108323 & 0.2710 \\
\hline LDR? & 0.001549 & 0.010501 & 0.147510 & 0.8831 \\
\hline LTTA? & -0.157789 & 0.081260 & -1.941786 & 0.0556 \\
\hline NPL? & -0.342325 & 0.147173 & -2.326005 & 0.0225 \\
\hline CAR? & 0.021471 & 0.010685 & 2.009418 & 0.0478 \\
\hline LTA? & 16.16764 & 1.544600 & 10.46720 & 0.0000 \\
\hline & Effects Spe & & & \\
\hline & & & S.D. & Rho \\
\hline Period random & & & 8.64E-06 & 0.0000 \\
\hline Idiosyncratic random & & & 7.402029 & 1.0000 \\
\hline & Weighted 5 & & & \\
\hline R-squared & 0.656700 & \multicolumn{2}{|c|}{ Mean dependent var. } & -11.02822 \\
\hline Adjusted R-squared & 0.622794 & \multicolumn{2}{|c|}{ S.D. dependent var. } & 16.89871 \\
\hline S.E. of regression & 10.37870 & \multicolumn{2}{|c|}{ Sum squared resid. } & 8725.113 \\
\hline F-statistic & 19.36814 & \multicolumn{2}{|c|}{ Durbin-Watson stat. } & 1.384420 \\
\hline \multirow[t]{2}{*}{ Prob. (F-statistic) } & 0.000000 & & & \\
\hline & \multicolumn{2}{|c|}{ Unweighted Statistics } & & \\
\hline R-squared & 0.656700 & \multicolumn{2}{|c|}{ Mean dependent var. } & -11.02822 \\
\hline Sum squared resid. & 8725.113 & \multicolumn{2}{|c|}{ Durbin-Watson stat } & 1.384420 \\
\hline
\end{tabular}

Table 4. Regression Analysis on Industry Performance of Rural Banks (BPR) in Southeast Sulawesi Province, Indonesia

\begin{tabular}{|l|l|l|}
\hline \multicolumn{2}{|c|}{ Variable } & Dependent variable \\
\cline { 3 - 3 } \multicolumn{2}{|c|}{} & ROA \\
\cline { 3 - 3 } \multicolumn{2}{|c|}{} & $\mathrm{R} 2$ \\
\hline Constanta & & -374.7360 \\
\hline Market concentration (MC) & $\beta_{1}$ & $-0.006886^{* * *}$ \\
\hline Market share deposit(MSD) & $\beta_{2}$ & $0.407543^{* *}$ \\
\hline Inflation Growth (PIFL) & $\beta_{3}$ & 1.851519 \\
\hline Loan to deposit ratio (LDR) & $\beta_{4}$ & 0.001549 \\
\hline Liabilities to total assets (LTTA) & $\beta_{5}$ & $-0.157789^{*}$ \\
\hline Non-Performing Loan (NPL) & $\beta_{6}$ & $-0.342325^{* *}$ \\
\hline Capital to adequacy ratio (CAR) & $\beta_{7}$ & $0.021471^{* *}$ \\
\hline Log to total assets (LTA) & $\beta_{8}$ & $16.16764^{\star * *}$ \\
\hline R-squared & & 0.656700 \\
\hline Adjusted R-sq. & & 0.622794 \\
\hline F-statistic & & 19.36814 \\
\hline Prob. (F-stat.) & & .000000 \\
\hline
\end{tabular}

${ }^{* * *}=$ Significant $.01 ;{ }^{* *}=$ Significant.05; ${ }^{*}=$ Significant .1.

These findings support previous research, which stated that high market concentration would reduce the performance of BPR Industry due to high lending costs, which in turn would reduce their level of competition in banking market; so, the effect of market concentrations still large, although the costs have not been proportional to income (Chirwa, 2001; Molyneux and Forbes, 1995; Wihana, Jaya and Wanto, 1998). Share deposit (MSD) have a positive 
effect on the performance of BPR industry. This means that the accumulation of highly efficient use of public funds resulting in the small interest of deposit that must be borne by BPR bank in its operations, though in quantity the cost of deposits is still small. Furthermore, market share of BPR bank industry in Southeast Sulawesi province is still small, resulting in a very high level of competition in obtaining customers. Therefore, the accumulation of public funds in BPR bank is still small, and tends to concentrate in several large banks and rural banks. This has weakened the level of competition that resulted in inefficiency of resource allocation. This research is supported by the concept suggested by Smirlock (1985) and Chirwa (2001) claiming that the market share is better than the market concentration because the efficiency of some banks in their maximal operations will obtain benefit above normal due to the efficiency of the operation.

The findings of this study indicate that the growth of inflation has no effect on the performance of BPR bank industry in Southeast Sulawesi province. This means that the rise and fall of the inflation rate did not have an impact on BPR bank loan interest rate, and this has not been able to increase revenue. This is supported by Perry (1992) who suggests that the effects of inflation on bank performance depend on whether inflation is anticipated or not. If the inflation is fully anticipated by adjustment of interest rate, the result will has a positive effect on profits or otherwise, if inflation is not anticipated by the adjustment to the interest rate, inflation will not contribute to the performance.

The results also indicate that the loan to deposit ratio has no effect on the performance of the BPR bank industry. This indicates that the size of the loan to deposit ratio has not been able to improve the performance of BPR bank industry in Southeast Sulawesi province because the provision of credit to customers has not been able to guarantee the liabilities of BPR banks at the request of depositor swilling to withdraw their funds.

In addition, the high ratio of loan to deposit has reduced the ability of liquidity of BPR banks operating in Southeast Sulawesi province, because the necessary funds to finance credit are getting larger that it is not proportional to the amount of customer deposits reaching an average of $117.6127 \%$ with a standard deviation large enough, reaching $74.33592 \%$. This study's findings are supported by the conceptual formulation of Ahmed and Khababa (1999) who found that the loan to deposit ratio of banks is the main variable and largely determines the performance of BPR banks.

Furthermore, Liabilities to total assets negatively affect performance of BPR bank industry. This means that the magnitude that Liabilities to total assets of operating BPR banks has lowered the achievement of banks, meaning the greater ratio will weaken the capital because the amount of debt is greater than the total assets owned by BPR banks. Therefore, the bank will bear the enormous cost of interest. Besides, the BPR banks in Southeast Sulawesi have not used debts efficiently as invested capital, making a lot of funds still unproductive investments. Therefore, the risk liability of the bank will increase resulting in lower bank achievement.

This finding is supported by Basir's (2000) contention that greater ratio weakens the capital because the bank will bear the interest costs of its customers. Besides, Aguirre and Lee (2001) found that low capital will increase the risk of the bank's operations as a result of the huge liability leading to low performance.

Non-Proforming Loan (NPL) bhas a negative effect on the performance of BPR bank industry. This suggests that large bad credit has reduced the performance of BPR bank industry in Southeast Sulawesi, and otherwise small bad credit will improve the industrial performance of BPR. One of the risks posed by the growing complexity of banking activities was that the emergence of non-performing loans (NPL) were getting bigger. In other words the greater the scale of operations of a bank, the lower the supervision aspect was, and NPL would be or the greater the credit risk (Vishnu Mawardi, 2005).

Capital adequacy ratio (CAR) had a positive effect on the performance of BPR bank industry in Southeast Sulawesi. This means that large Capital to adequacy ratio (CAR) contributed to the performance of BPR banks because the total assets owned were able to cover the risk arising from the assets of investment risk. 
Furthermore, the capital of BPR banks increased because of Southeast Sulawesi provincial government's policies to help BPR reach an average of $37.52 \%$ as a consequence of the local government wanted to ensure that the customers' funds in BPR banks is still are operating. Therefore, due to an increase in Capital to adequacy ratio (CAR), the bank has been able to bear the burden of liability used in banking operations. This finding is supported by Bourke's (1989) research findings in the countries of Europe, North America, and Australia, concluding that that capital was needed as a source of cheap funds.By an increase in the capital ratios of banks will increase credit portfolio so as to be able to increase profits.

The findings of this study indicated that there was a positive correlation between Loq of total assets and the performance of BPR bank Industry in Southeast Sulawesi province. This implies that the large number of bank shas increased the performance of banks because the BPR banks operating ind Southeast Sulawesi have different economic scales that the competition in recruiting customers is very tough. This research finding is also supported by Alper and Anbar (2011) claiming that bank size us a determining factor in profit gain Turkey's banks.

Studies conducted by Smirlock (1985) formulates that large size banks possibly provided reserve funds that could be used to invest massively, and they were easier in providing lending. This is in line with the formulation by Chirwa (2001) and Sarita (2012) that the size of banks is a variable that is used to measure the difference in economic scale banks, therefore, compared to small banks, large banks will be able to dominate the large economies of scale because they have the opportunity to diversify their investments.

While the supporting research (Awdeh, 2005; Akhigbe and McNulty, 2003) states that the increase in total assets will provide more investment opportunities for banking institutions and ensure the long term investment of BPRbanks will increase profits.

\section{CONCLUSION}

This research has linked several variables to show the contribution of Market concentration (MC), Market share Deposit (MSD), bank macroeconomic variables, and bankspecific variables on the performance of BPR Industry in Southeast Sulawesi. Thus, the use of models built on the theory of SCP, RE can determine the performance of the BPR bank industry.

Market structure and relative efficiency were factors that affected the performance of BPR bank industry in Southeast Sulawesi. The results of tests showed that the market structure had a negative effect on of the performance of BPR industry, while the relative efficiency had a positive effect on the performance of BPR bank industry.

The results of the suggested that the market structure and the relative efficiency could explain changes in the performance of the BPR bank industry in Southeast Sulawesi Province. This means that the when the market concentrated it would reduce the performance of the BPR bank industry, and conversely, the higher the increase of relative efficiency the better the performance of BPR bank industry.

This study also theorized that greater amount of market share and greater capital adequacy ratio (CAR) and log to total assets (LTA) as the size of banks improved the performance of BPR bank industry. In the contrast, the high concentrated of the market, increasing liabilities to total assets (LTTA), and growing non-Performing Loan (NPL) lowered the performance BPR bank industry

Furthermore, this study also theorized that the amount of loans given to customers as compared to the amount of customer deposits and the amount of inflation growth were not able to contribute to improving the performance of BPR bank industry in Southeast Sulawesi Province. This indicates that there were still many BPR banks operating during the study period that were not able to raise funds from third parties, so that the loans granted to customers still came mostly from loans from major banks.

Conceptually, this study was carried out systematically based on valid research methods, but there were still a number of weaknesses because many variables were not 
included in this model, which would likely to influence the performance of BPR bank industry Southeast Sulawesi.

Further researchers are suggested considering macroeconomic variables such as GDP and interest rate in the place of growth of inflation variable. In addition, there are still bankspecial variables that will fundamentally affecting the performance of both conventional and BPR banks, such as operational costs of the bank (ROA),

\section{REFERENCES}

1. Ali, Masyhud, (2006), Manajemen Risiko: Strategi Perbankan and DuniaUsaha Menghadapi Tantangan Globalisasi Bisnis, Rajawali Pers, Jakarta.

2. Aguirre, M. S., \& Lee, T. K. (2001). A Reevaluation of the market structure performance relationship for Banks under Different Regimes. pp. 1 - 34.

3. Alper, D. and Anbar, A. (2011). Bank specific and macroeconomic determinants of commercial bank profitability: empirical evidence from Turkey. Business and Economic Research Journal, 2(2), 139-152.

4. Athanasoglou, P. P., Brissimis, S.N., \& Delis, M. D. (2005). Bank-specific, industryspecific and macroeconomic determinant of bank profitability. Working Paper, Bank of Greece 25, 1 - 37.

5. Athanasoglou, P.P., Brissimis, S.N. \& Delis, M.D. 2008, "Bank-specific industryspecific and macroeconomics determinants of bank profitability", Journal ofInternational Financial Markets, Institutions and Money, vol. 18, no. 2, pp. 121-136.

6. Arsadi, N., \& Lawrence, E. C. (1987). An empirical investigation of new bank performance. Journal of Banking and Finance, 11, 33 - 48.

7. Bourke, P. (1989). Concentration and other determinant of bank profitability in Europe, North America and Australia. Journal of Banking and Finance, 13, 65 - 79.

8. Chirwa, E.W.T. (2001). Market structure, liberalization and performance in the Malawian banking industry. AERC Research Paper, 108, 1 - 55.

9. Dietrich, A. and Wanzenried, G. (2011). Determinants of bank profitability before and during the crisis: evidence from Switzerland. Journal of International Financial Markets, Institutions and Money, forthcoming.

10. DeYoung, R., \& Hasan, I. (1998). The performance of de novo commercial banks: A profit efficiency approach. Journal of Banking \& Finance, 22, 565 - 587.

11. Demirgüç-Kunt, A. and A. Huizinga (1998). "Determinants of Commercial Bank Interest Margins and Profitabilitas: Some International Evidence," World Bank Economic Review 13, 379-408.

12. Fu, X., \& Hefferman, S. (2005). China: The effects of bank reform on structure and performance. Working Paper Cass Business School, City University, London.

13. Gilbert, R.A. (1984b). Bank market structure and competition: A survey. Journal of Money, Credit and Banking, 16, (4), $617-645$.

14. Goldberg \& Rai. (1996). The structure-performance relationship for European banking. Journal of Banking \& Finance, 20, 745 - 771.

15. Guru, B. K., Staunton, J., \& Shanmugam, B. (2000) Determinants of commercial bank profitability in Malaysia. Asian Academy of Management Journal, 5, (2), 1 - 22

16. Hannan, T.H. (1991). Bank commercial loan market and the role of market structure: evidence from surveys of commercial lending. Journal of Banking and Finance, 15, 133 149.

17. Heggestad, A.A., \& Mingo, J.J. (1977). The competitive condition of US banking markets and the impact of structural reform, Journal of Finance, 32, 649-61.

18. Kharawish, H.A, (2011) Determinants of Commercial Banks Performance: Evident from Jordan, International Research Journal of Finance and Economics ISSN 1450-2887 Issue 81 (2011).

19. King, R. G., \& Levine, R. (1993). Finance and growth: Schumputer might be right, Quarterly Journal of Economics, 108, 513 - 542. 
20. Kuncoro, M. (2003). Metode Riset Untuk Bisnis and Ekonomi. Penerbit Erlangga Indonesia Laporan Tahunan Bank Indonesia 2012.

21. Levine, Ross. 1996. Financial development and economic growth. Policy Research Paper. 1678, The World Bank (forthcoming in Journal of Economic Literature).

22. Lloyd-Wlliams, D.M., Molyneux, P., \& Thornton, J. (1994), Market structure and performance in Spanish banking. Journal of Banking \& Finance, 18, 433 - 443.

23. Molyneux, P., \& Forbes, W. (1995). Market structure and performance in European banking. Applied Economics, 27, 155 -159.

24. Molyneux, P., \& Thornton, J. (1992). Determinants of European Bank Profitability: A Note. Journal of Banking and Finance, 16, (6), $1173-1178$.

25. More, C., \& Nagy, M. (2003). Relationship between market structure and bank performance: Empirical evidence for central and eastern Europe. MNB Working Paper, 1 $-32$.

26. Osborne, D.K., \& Wendel, J. (1983). Research in structure, conduct and performance in banking 1964-1979. Research Paper, 83 - 003, College of Business Administration, Oklahoma State University.

27. Pasiouras, F. and Kosmidou, K. (2007). Factors influencing the profitability of domestic and foreign commercial banks in the European Union. Research in International Business and Finance, 21(2), 222-237.

28. Peng, T. L. (1998). The Business of Banking in Malaysia. Pelanduk publications (M) Sdn Bhd. Slangor Darul Eshan, Malaysia.

29. Perry, P. (1992), "Do Banks Gain or Lose from Inflation?" Journal of Retail Banking, Vol. 14, No. 2, 25-30.

30. Rasiah, D. (2010). Theoretical framework of profitability as applied to commercial banks in Malaysia. European Journal of Economics, Finance and Administrative Sciences, 19, 74-97.

31. Rhoades, S.A. (1982). Welfare loss, redistribution effect, and restriction of output due to monopoly. Journal of Monetary Economics, 9, 375 - 387.

32. Sastrosuwito, S and Suzuki, Y (2012) The Determinants of Post-Crisis Indonesian Banking System Profitability, Economics and Finance Review Vol. 1(11) pp. 48 - 57, January, 2012 ISSN: 2047.

33. Sarita, B., Zandi, G. R., Shahabi, A. (2012) Determinants of Performance in Indonesian Banking: A Cross-sectional and Dynamic Panel Data Analysis, International Journal of Economics and Finance Studies Vol 4, No 2, 2012 ISSN: 1309-8055 (Online).

34. Smirlock, M. (1985). Evidence of (non) relationship between concentration and profitability in banking. Journal of Money and Banking, 17, 69 - 83.

35. Smirlock, M., Gilligan, T., \& Marshall, W. (1986). Tobin's q and the structure-performance relationship: Reply, The American Economic Review, 76 (5), pp. 1211-1213.

36. Spellman, L.J. (1981). Commercial banks and the profits of savings and loan markets. Journal of Bank Research, 12, 32 - 36. www.businessnews.co.id 27 July 2011.

37. Rivai and Andria. 2009. Bank and Financial Institution Management. Jakarta: PT Raja Grafindo Persada. 